\title{
Nurture trumps nature in shaping oral bacterial communities in children
}

Chiranjit Mukherjee

Christina O. Moyer

Heidi M. Steinkamp

Shahr B. Hashmi

Clifford J. Beall

Xiaohan Guo

Ai Ni

Eugene J. Leys

Ann L. Griffen

\section{Video Byte}

Keywords: Microbiome, oral microbiota, oral microbiome, acquisition, strain level, species level, human, parent-to-child transmission, genetics, nature versus nurture, mother-child dyad, host genetics, environment, microbial transmission, heritability, oral health, dental caries, periodontal disease, biologic children, adopted children

Posted Date: March 11th, 2021

DOl: https://doi.org/10.21203/rs.3.rs-318779/v1

License: (9) This work is licensed under a Creative Commons Attribution 4.0 International License. Read Full License 


\section{Abstract}

At birth, the mouth is sterile and relatively germ-free. It's only later that bacteria colonize the mouths of children. But little is understood about how and why certain bacteria triumph over others some of which are responsible for spreading diseases such as dental caries and periodontal disease. It's a question of what matters more: genetics or environment, nature or nurture? To find out researchers compared the mouths of two groups of people. Parents and their biological children and parents and their adopted children. This design helped researchers separate genetic factors from environmental ones affecting the oral microbiota. Results showed no differences in how closely oral bacterial profiles matched between adoptive versus biological mother-child pairs. In fact, the oral microbiomes of all children more closely resembled those of their own mothers than those of unrelated women suggesting that contact and shared environment play a bigger role than genetics alone. And fathers shared microbes with their children just as often as mothers did. Future work will examine how microbial communities assemble through childhood and how environmental factors such as diet shape these communities and oral health into adulthood. 